\title{
W. Kapłonek
}

Politechnika Koszalińska, Wydział Mechaniczny, Katedra Inżynierii Produkcji, ul. Racławicka 15-17, 75-620 Koszalin, Polska

\section{ZASTOSOWANIE METODY NAKŁADANIA OBRAZÓW DO OCENY MIKRONIERÓWNOŚCI POWIERZCHI W RUCHU}

\author{
STRESZCZENIE
}

\begin{abstract}
W referacie przedstawiono jedną z komputerowych metod przetwarzania obrazów ruchomych, określaną angielskim terminem image stacking, co oznacza nakładanie obrazów, przeznaczoną do oceny mikronierówności powierzchni. W badaniach wykorzystano ruchome obrazy kątowego rozkładu natężenia światła rozproszonego uzyskane w wyniku odbicia wiązki światła laserowego o długości fali $\lambda=635 \mathrm{~nm}$ padającej równolegle i prostopadle do śladów obróbki pod kątem $50^{\circ}$. Badano powierzchnię wałka polerowanego $\left(R_{a}=0,04 \mu \mathrm{m}\right)$ obracającego się z prędkością obrotową $n_{w}=685 \mathrm{obr} / \mathrm{min}$. Obrazy przetwarzano za pomocą oprogramowania RegiStax wydzielając pojedyncze klatki sekwencji video, pozycjonując je i nakładając, a uzyskany obraz wynikowy poddawano dodatkowo filtrowaniu za pomocą filtrów falkowych. Analizę uzyskanych obrazów przeprowadzono za pomocą oprogramowania ImagePro ${ }^{\circledR}$ Plus wyznaczając parametry geometryczne charakteryzujące oceniane obrazy.
\end{abstract}

Stowa kluczowe: metoda nakładania obrazów, chropowatość powierzchni, ruch powierzchni

\section{WPROWADZENIE}

Niezwykle szybki rozwój techniki komputerowej w ostatnich latach przyniósł znaczny postęp w dziedzinie przetwarzania i analizy obrazu cyfrowego [1]. Również $\mathrm{w}$ badaniach struktury geometrycznej powierzchni przetwarzanie i analizę obrazu wykorzystuje się dość często zwłaszcza w połączeniu $\mathrm{z}$ optycznymi metodami pomiarowymi $[2,3,4]$. Pozwala to znacznie lepiej przedstawić naturę procesów obróbkowych, jak i analizować powstające $\mathrm{w}$ ich wyniku powierzchnie pod względem ich określonych parametrów (chropowatość, falistość). Analiza taka umożliwia szybkie wykrycie wad, uszkodzeń lub zniekształceń powierzchni części maszyn mających wpływ na utrzymanie korzystnych warunków eksploatacyjnych podczas całego okresu ich użytkowania. W Katedrze Inżynierii Produkcji Politechniki Koszalińskiej od wielu lat rozwija się optyczne metody pomiarowe przeznaczone do oceny mikronierówności powierzchni. Ostatnio zainteresowano się możliwością połączenia takich metod $\mathrm{z}$ technikami przetwarzania i analizy obrazu. Dotyczy to głównie tych przypadków, w których oceny powierzchni dokonuje się podczas ruchu. Jedną z metod przetwarzania obrazów ruchomych, jest metoda określana angielskim terminem image stacking [5], co oznacza nakładanie obrazów. Polega ona na nałożeniu na siebie wielu wyodrębnionych klatek z obrazu ruchomego tak, aby powstał pojedynczy obraz wynikowy. Przed 
nałożeniem klatki pozycjonowane są względem wybranego punktu, wspólnego dla wszystkich obrazów. Następnie klatki są łączone, co powoduje uśrednianie ich wartości, a obraz wynikowy może być dodatkowo poddany filtrowaniu. Ma to na celu uzyskanie z obrazu ruchomego takiej samej (lub zbliżonej) jakości odwzorowania badanej powierzchni jak z obrazu uzyskanego w warunkach statycznych. Dzieje się tak w wyniku zwiększenia stosunku sygnału do szumu oraz wzrostu zakresu dynamicznego sygnału zawartego w obrazie. Uzyskanie zbliżonej jakości obrazów i późniejsza ich analiza ma duże znaczenie w przypadku kontroli i diagnostyki stanu powierzchni części maszyn znajdujących się w ruchu, bowiem często pomiar lub ocena stanu powierzchni muszą być wykonane podczas obróbki tych części. Metoda nakładania obrazów najczęściej wykorzystywana jest w takich dziedzinach jak: astronomia [6], medycyna [7], geofizyka [8] i grafika reklamowa. Natomiast jej praktycznym zastosowaniem są stabilizatory obrazu produkowanych obecnie cyfrowych aparatów fotograficznych i kamer video.

\section{METODYKA BADAŃ}

Prowadzone badania doświadczalne miały charakter wstępny i były kontynuacją wcześniejszych prac, których wyniki szczegółowo opisano m.in. w [9]. W niniejszym przypadku skupiono się jedynie na zastosowaniu opisanej metody przetwarzania obrazu w kontekście polepszenia jakości uzyskiwanych obrazów ruchomych m.in. poprzez zastosowanie filtrów falkowych i korekcji tonalnej. Do badań wytypowano cztery sekwencje obrazów kątowego rozkładu natężenia światła rozproszonego uzyskane w wyniku odbicia wiązki światła laserowego o długości fali $\lambda=635 \mathrm{~nm}$ padającej pod kątem $50^{\circ}$. Badano powierzchnię wałka polerowanego $\left(R_{a}=0,04 \mu \mathrm{m}\right)$. Pierwsze dwie sekwencje zawierały obrazy rejestrowane $\mathrm{w}$ warunkach statycznych oraz $\mathrm{w}$ ruchu z prędkością obrotową $n_{w}=685 \mathrm{obr} / \mathrm{min}$ podczas oświetlania powierzchni równolegle do śladów obróbki, natomiast dwie pozostałe sekwencje podczas oświetlania powierzchni prostopadle do śladów obróbki. Rodzaje i parametry zarejestrowanych obrazów przedstawiono $\mathrm{w}$ tabl. 1, natomiast ich wygląd pokazano na rys.1.

Table 1. Rodzaje i parametry rejestrowanych obrazów światła rozproszonego

\begin{tabular}{|c|c|c|c|c|c|c|}
\hline $\begin{array}{c}\mathrm{Nr} \\
\text { obrazu }\end{array}$ & $\begin{array}{l}\text { Kierunek } \\
\text { oświetla- } \\
\text { nia powie- } \\
\text { rzchni }\end{array}$ & $\begin{array}{c}\text { Prędkość } \\
\text { obrotowa } \\
\text { próbki } \\
n_{w}, \\
\text { [obr/min] }\end{array}$ & $\begin{array}{l}\text { Typ } \\
\text { pliku }\end{array}$ & $\begin{array}{l}\text { Rozdziel- } \\
\text { czość } \\
\text { obrazu } \\
\text { [piksele] }\end{array}$ & $\begin{array}{c}\text { Długość } \\
\text { sekwen- } \\
\text { cji video } \\
\text { [s] }\end{array}$ & $\begin{array}{l}\text { Urządzenie } \\
\text { rejestrujące }\end{array}$ \\
\hline 1 & $\|$ & - & *.jpg & $640 \times 480$ & - & \multirow{4}{*}{$\begin{array}{c}\text { Cyfrowy } \\
\text { aparat } \\
\text { fotograficzny } \\
\text { Olympus } \\
\text { Camedia } \\
\text { C-5060 WZ }\end{array}$} \\
\hline 2 & $\|$ & 685 & *.mov & $640 \times 480$ & 10 & \\
\hline 3 & $\perp$ & - & *.jpg & $640 \times 480$ & - & \\
\hline 4 & $\perp$ & 685 & *.mov & $640 \times 480$ & 10 & \\
\hline
\end{tabular}




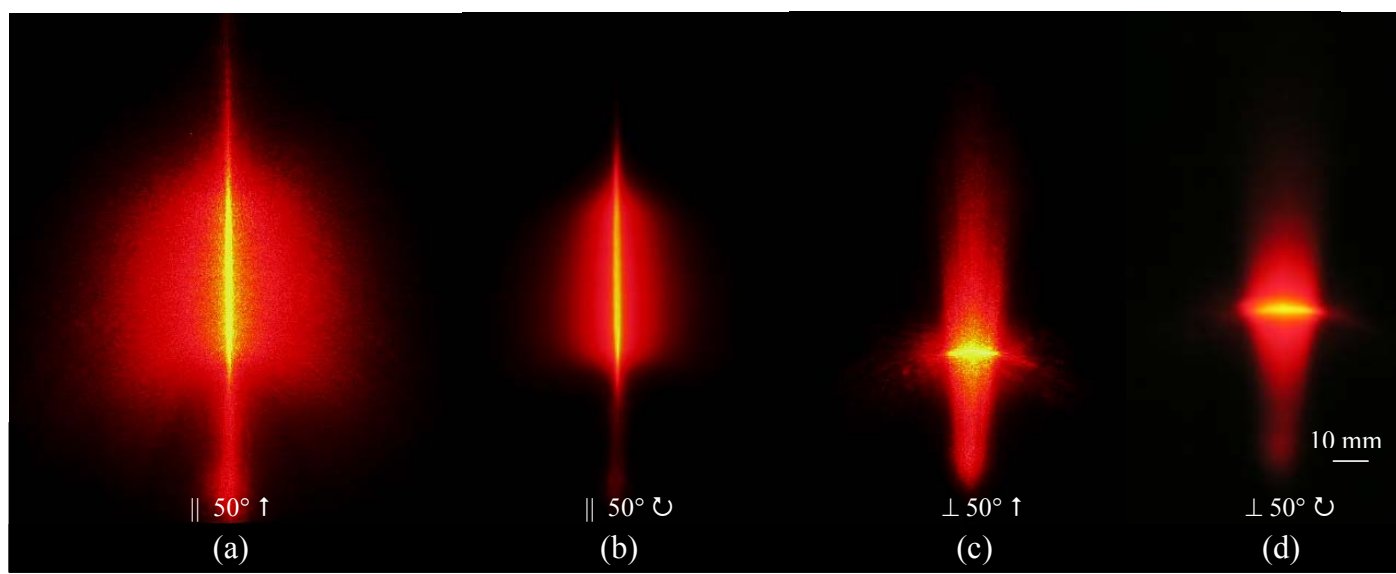

Rys. 1. Obrazy kątowego rozkładu natężenia światła rozproszonego przez powierzchnię wałka polerowanego $\left(R_{a}=0,04 \mu \mathrm{m}\right)$ uzyskane w wyniku odbicia światła laserowego o długości fali $\lambda=635 \mathrm{~nm}$ padającej pod kątem $50^{\circ}$ równolegle $(a, b)$ i prostopadle $(c, d)$ do śladów obróbki: a) w warunkach statycznych,

b) podczas ruchu $z$ prędkościa obrotową $n_{w}=685 \mathrm{obr} / \mathrm{min}, \mathrm{c}$ ) $\mathrm{w}$ warunkach statycznych, d) podczas ruchu $\mathrm{z}$ prędkością obrotową $\mathrm{n}_{\mathrm{w}}=685 \mathrm{obr} / \mathrm{min}$

Do przetwarzania obrazów wykorzystano oprogramowanie o nazwie RegiStax 4.0 [10]. Jest to zaawansowany program typu freeware rozwijany przez Cora Berrevoetsa, składający się z pięciu głównych modułów odpowiadających kolejnym etapom przetwarzania obrazów. Algorytm działania programu pokazano na rysunku 2.

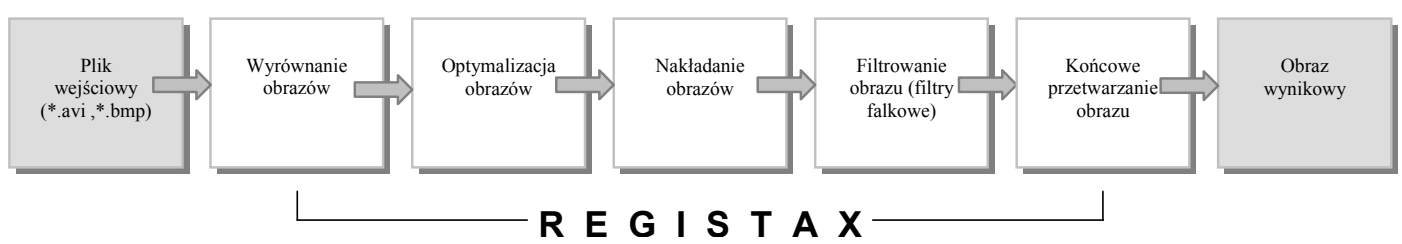

Rys. 2. Algorytm przetwarzania obrazów realizowany przez program RegiStax 4.0

Z zarejestrowanych sekwencji video program wydzielił pojedyncze klatki (dla 10 sekundowej sekwencji uzyskano 300 klatek). Po wybraniu klatki referencyjnej, stanowiącej obraz odniesienia do wyrównania pozostałych klatek, program automatycznie dokonał ich wyrównania. Po tej operacji, obrazy zostały poddane optymalizacji polegającej na odrzuceniu klatek o gorszej jakości (program odrzucił 37 klatek). Następnie klatki zostały nałożone w wyniku, czego powstał pojedynczy obraz wynikowy o uśrednionej wartości. Po porównaniu go $\mathrm{z}$ obrazem uzyskanym $\mathrm{w}$ warunkach statycznych stwierdzono, że ich zgodność jest niewielka. Postanowiono dokonać dalszego przetwarzania wykorzystując filtry falkowe dostępne w module Wavelet, pokazanym na rys. 3. Dla każdego obrazu uzyskanego z sekwencji video stosowano 4 ustawienia, łącząc rodzaj filtra falkowego z typem rozwarstwienia: 1 - Default i Linear, 2 -Gaussian i Linear, 3 -Default i Dyadic, 4 -Gaussian i Dyadic. Dokładne ustawienia filtrów, rozwarstwień i wartości podano w tabl. 2, natomiast na rys. 4 pokazano przykładowy zestawy obrazów w różnych fazach przetwarzania za pomocą filtrów falkowych, otrzymany dla prostopadłego oświetlania badanej powierzchni. 


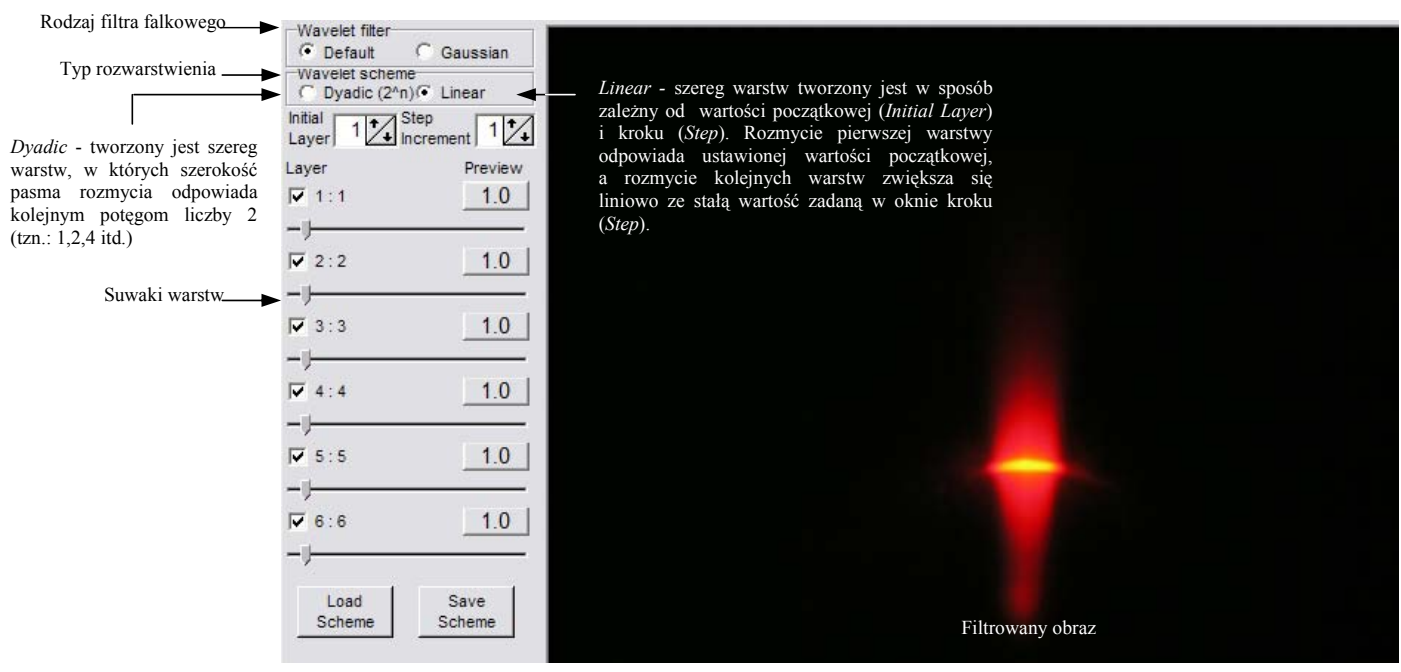

Rys. 3. Okno modułu Wavelet programu RegiStax 4.0, służącego do przetwarzania obrazów z wykorzystaniem filtrów falkowych

Table 2. Ustawienia filtrów falkowych

\begin{tabular}{|c|c|c|c|c|}
\hline Typ filtra falkowego & Default & Gaussian & Default & Gaussian \\
\hline Typ rozwarstwienia & Linear & Linear & Dyadic & Dyadic \\
\hline Wartość początkowa & 1 & 1 & - & - \\
\hline Krok & 1 & 1 & - & - \\
\hline & $1 / 1,1$ & $1 / 1,1$ & $1 / 32,9$ & $1 / 81,0$ \\
Numer suwaka & $2 / 100$ & $2 / 100$ & $2 / 61,0$ & $2 / 80,5$ \\
warstw / zadana & $3 / 9,8$ & $3 / 1,1$ & $3 / 78,5$ & $3 / 84,5$ \\
wartość & $4 / 9,8$ & $4 / 35,4$ & $4 / 73,1$ & $4 / 69,0$ \\
& $5 / 1,1$ & $5 / 10,5$ & $5 / 1,1$ & $5 / 69,0$ \\
& $6 / 1,1$ & $6 / 1,1$ & $6 / 1,1$ & $6 / 1,1$ \\
\hline
\end{tabular}

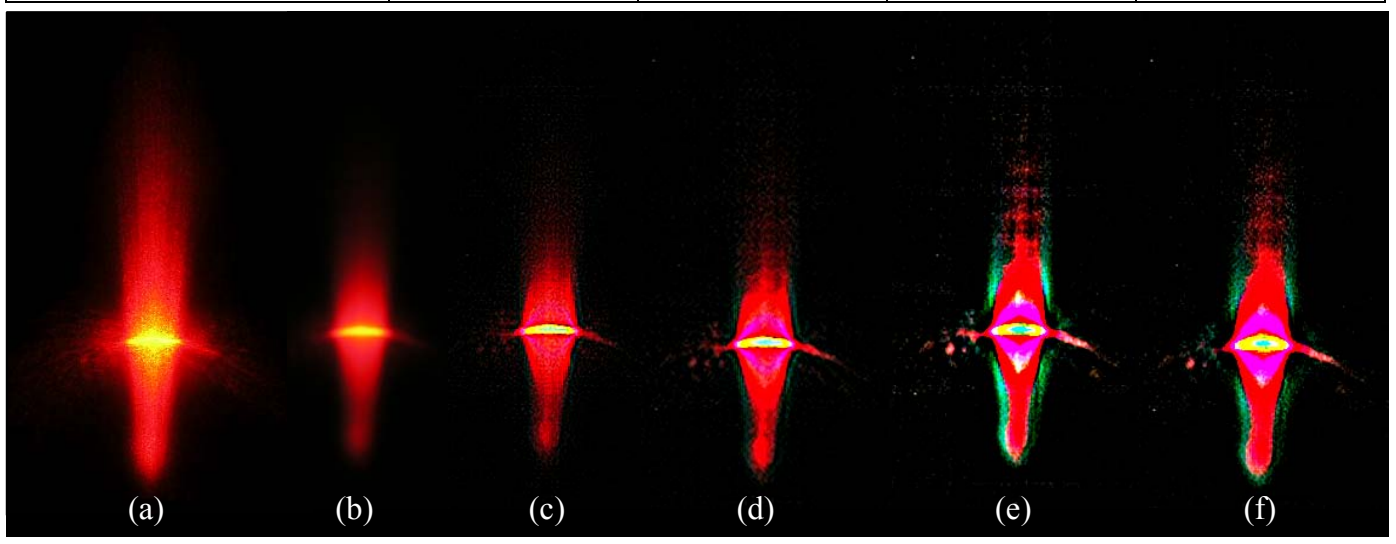

Rys. 4. Zestawienie obrazów światła rozproszonego zarejestrowanych podczas oświetlania powierzchni polerowanej $\left(R_{a}=0,04 \mu \mathrm{m}\right)$ światłem laserowym o długości fali $\lambda=635 \mathrm{~nm}$ prostopadle do śladów obróbki pod katem $50^{\circ}$ : a) obraz zarejestrowany w stanie statycznym, b) przetworzony obraz wyniko-

wy powstały przez nałożenie 263 klatek z sekwencji video zarejestrowanej dla prędkości obrotowej $\mathrm{n}_{\mathrm{w}}=685 \mathrm{obr} / \mathrm{min}, \mathrm{c}$ ) obraz po filtrowaniu (Default i Linear), d) obraz po filtrowaniu (Gaussian i Linear), e) obraz po filtrowaniu (Default i Dyadic), f) obraz po filtrowaniu (Gaussian i Dyadic) 
Ostatnim etapem przetwarzania obrazów w oprogramowaniu RegiStax 4.0 było poddanie obrazów po filtrowaniu falkowym korekcji tonalnej. Przykładowe obrazy po filtrowaniu falkowym i korekcji tonalnej otrzymane dla obrazów światła rozproszonego przy prostopadłym oświetlaniu badanej powierzchni pokazano na rys. 5 .

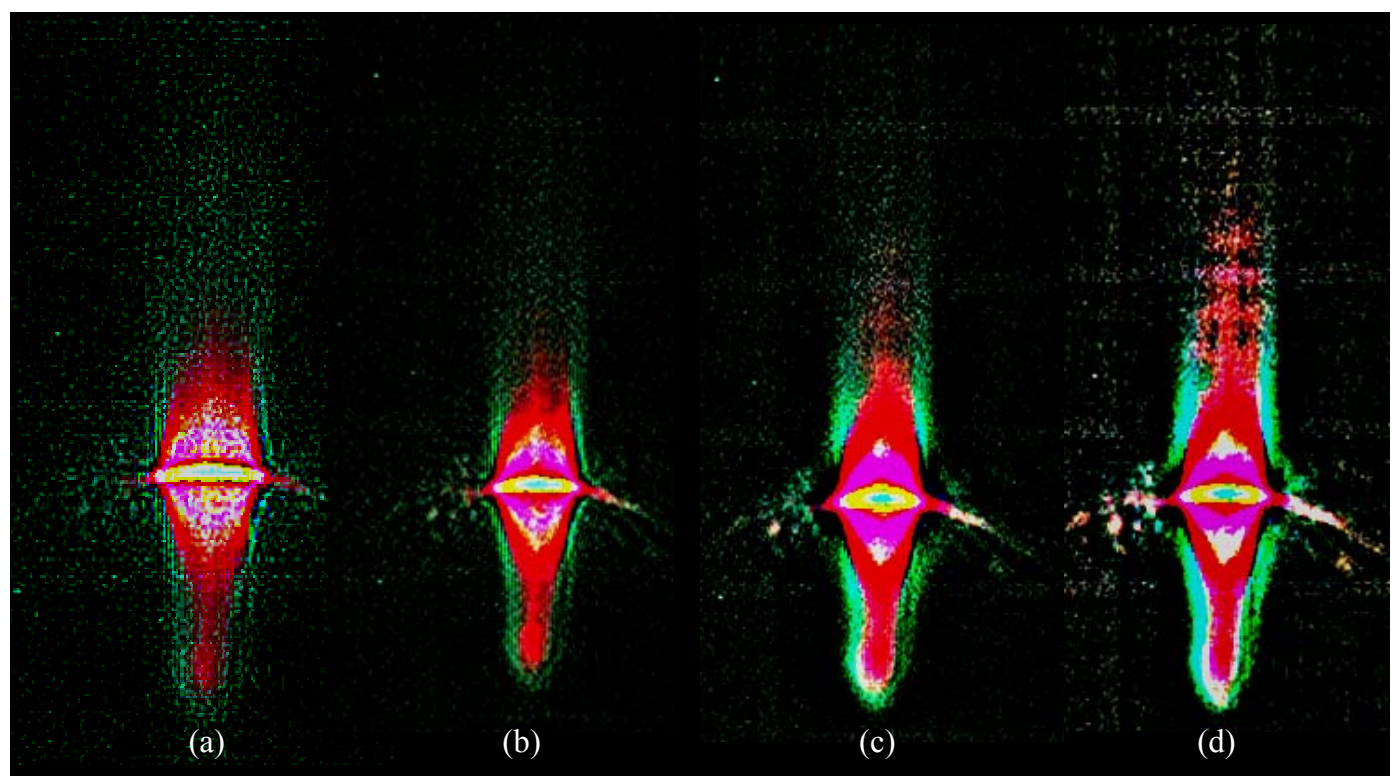

Rys. 5. Obrazy światła rozproszonego dla powierzchni polerowanej $\left(R_{a}=0,04 \mu m\right)$ oświetlanej światłem laserowym o długości fali $\lambda=635 \mathrm{~nm}$, prostopadle do śladów obróbki pod katem $50^{\circ}$ po przetwarzaniu z wykorzystaniem filtrów falkowych i korekcji tonalnej w oprogramowaniu RegiStax 4.0: a) obraz po filtrowaniu (Default i Linear), b) obraz po filtrowaniu (Gaussian i Linear), c) obraz po filtrowaniu (Default i Dyadic), d) obraz po filtrowaniu (Gaussian i Dyadic)

Przetworzone obrazy poddano następnie analizie za pomocą oprogramowania o nazwie Image-Pro ${ }^{\circledR}$ Plus 5.1 firmy Media Cybernetics, Inc., (USA) [11]. Jest to specjalistyczne środowisko przeznaczonym do badań naukowych, umożliwiające realizowanie takich funkcji jak: przechwytywanie i przetwarzanie obrazu, pomiary, analizę obrazu wraz $\mathrm{z}$ archiwizowaniem danych oraz tworzenie makr programowych $\mathrm{w}$ celu automatyzacji prowadzonych badań.

Program posłużył do wyznaczenia parametrów geometrycznych wyrażonych w pikselach takich jak: szerokość, długość oraz pole powierzchni ocenianych obrazów. Analiza prowadzona była na obrazach po filtrowaniu oraz na obrazach po filtrowaniu poddanych dodatkowo korekcji tonalnej. W każdym $\mathrm{z}$ tych przypadków program dokonał segmentacji, a następnie automatycznie wyliczył odpowiednie parametry geometryczne na podstawie liczby zliczonych obiektów w obrazie. Na rys. 6 pokazano przykładowy zestaw obrazów po segmentacji otrzymany dla równoległego oświetlania badanej powierzchni wraz z wynikami przeprowadzonej analizy. 

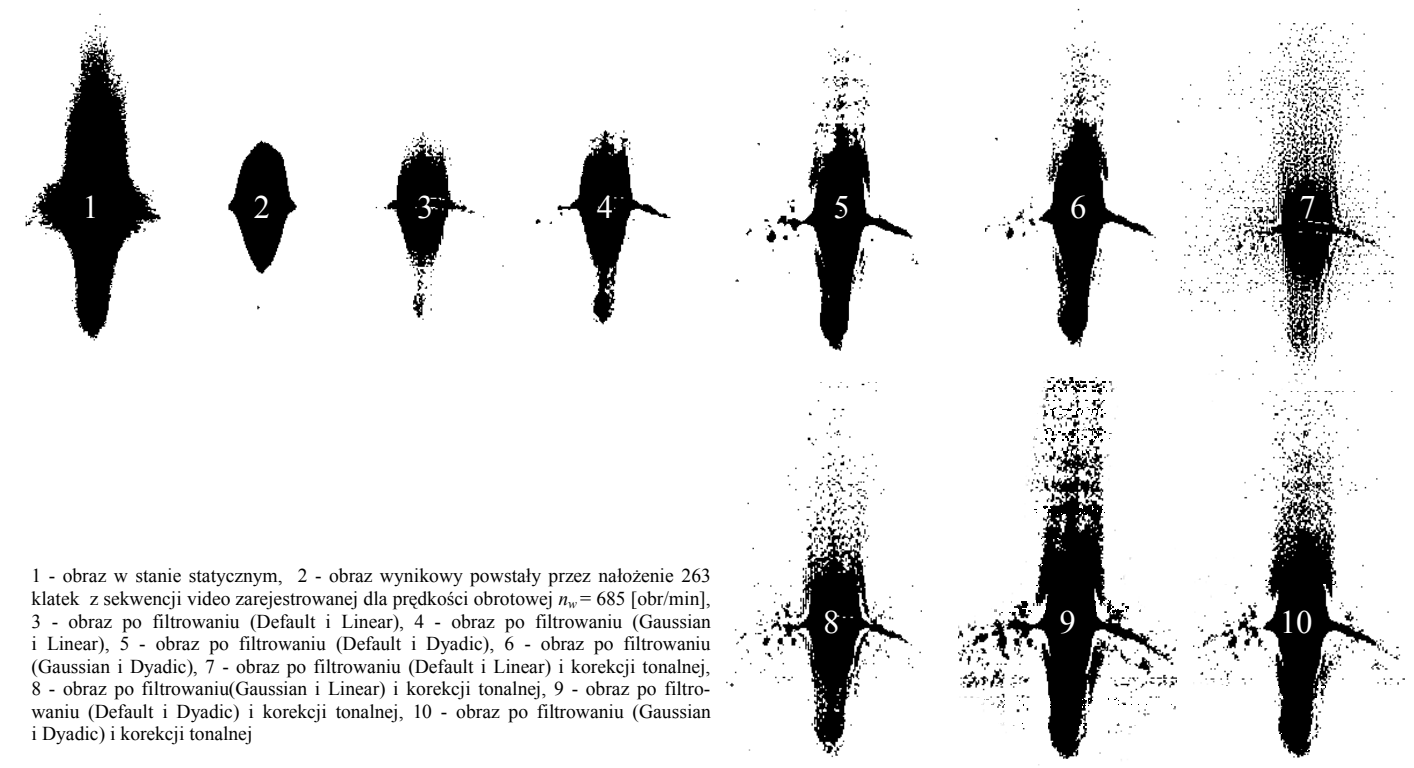

\begin{tabular}{|c|c|c|c|c|c|}
\hline $\begin{array}{c}\text { Numer } \\
\text { obrazu }\end{array}$ & $\begin{array}{c}\text { Pole } \\
\text { powierzchni } \\
\text { obrazu } \\
\text { [piksele] }\end{array}$ & $\begin{array}{c}\text { Długość } \\
\text { obrazu } \\
\text { [piksele] }\end{array}$ & $\begin{array}{c}\text { Szerokość } \\
\text { obrazu }\end{array}$ & $\begin{array}{c}\text { Całkowita } \\
\text { liczba } \\
\text { obiektów } \\
\text { w obrazie } \\
{[-]}\end{array}$ & $\begin{array}{c}\text { Liczba obiektów } \\
\text { w zakresie } \\
\text { pomiarowym }\end{array}$ \\
\hline 1 & 42953 & 394,92 & 213,77 & 597 & 14 \\
\hline 2 & 14969 & 245,99 & 102,01 & 2 & 1 \\
\hline 3 & 12852 & 434,47 & 86,98 & 568 & 45 \\
\hline 4 & 18447 & 437,19 & 137,62 & 2239 & 157 \\
\hline 5 & 12852 & 343,37 & 86,98 & 566 & 44 \\
\hline 6 & 22944 & 439,94 & 174,18 & 3699 & 268 \\
\hline 7 & 13981 & 432,92 & 83,93 & 258 & 251 \\
\hline 8 & 22894 & 436,98 & 162,13 & 3257 & 7 \\
\hline 9 & 14393 & 433,04 & 107,01 & 356 & 298 \\
\hline 10 & 27254 & 459,98 & 197,27 & 3678 & \\
\hline
\end{tabular}

Rys. 6. Przykładowe wyniki komputerowej analizy obrazu przeprowadzonej dla wałka polerowanego $\left(R_{a}=0,04 \mu \mathrm{m}\right)$ za pomoca oprogramowania Image-Pro ${ }^{\circledR}$ Plus 5.1: a) kontury otrzymane przez segmentację obrazu, dla obrazów zarejestrowanych podczas oświetlania powierzchni światłem laserowym o długości fali $\lambda=635 \mathrm{~nm}$, skierowanym prostopadle do śladów obróbki pod kątem $50^{\circ}$,

b) uzyskane parametry geometryczne

\section{WYNIKI I DYSKUSJA}

Na podstawie wyników analizy obrazu przeprowadzonych za pomocą oprogramowania Image-Pro ${ }^{\circledR}$ Plus 5.1 opracowano wykresy zależności pola powierzchni powstającego obrazu światła rozproszonego w zależności od numeru przetworzonego obrazu przedstawionego na rys. 6. Wykresy pokazane na rys. 7. przedstawiono dla dwóch przypadków, w których badaną powierzchnię wałka polerowanego $\left(R_{a}=0,04 \mu \mathrm{m}\right)$ oświetlano wiązką światła laserowego równolegle i prostopadle do śladów obróbki. 
Zastosowanie filtrów falkowych i korekcji tonalnej wpłynęło znacznie na polepszenie charakteru informacji z obrazów uzyskanych z sekwencji video. Jest to wyraźnie widoczne na obrazach zarejestrowanych podczas prostopadłego oświetlania powierzchni.
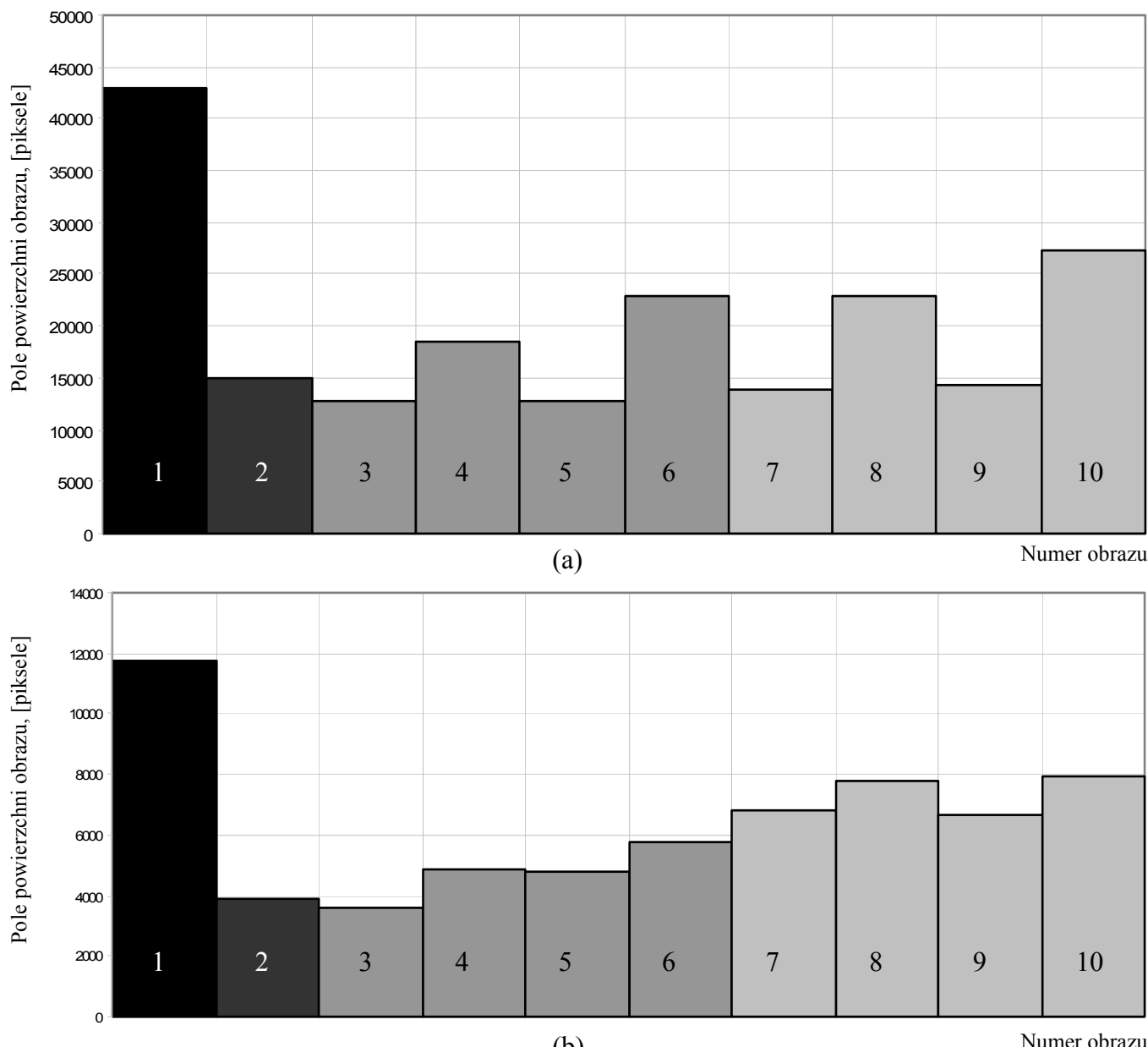

(b)

Rys. 7. Wykres zależności pola powierzchni powstającego obrazu światła rozproszonego od numeru przetworzonego obrazu pokazanego na rys. 6.: a) dla obrazów zarejestrowanych podczas oświetlania powierzchni światłem laserowym równolegle do śladów obróbki, b) dla obrazów zarejestrowanych podczas oświetlania powierzchni światłem laserowym prostopadle do śladów obróbki

\section{WNIOSKI}

Przeprowadzone badania wstępne pozwalają stwierdzić, że zaproponowana metoda przetwarzania obrazów może zostać $\mathrm{z}$ powodzeniem wykorzystana do oceny mikronierówności powierzchni będących $\mathrm{w}$ ruchu na podstawie zarejestrowanych obrazów kątowego rozkładu natężenia światła rozproszonego. Wykorzystane oprogramowanie RegiStax, realizujące w kolejnych krokach przetwarzanie obrazu ruchomego, jest potężnym narzędziem pozwalającym na uzyskanie uśrednionej wartości obrazu wynikowego i dodatkową jego korekcję m.in. poprzez zastosowaniu filtrów falkowych. Filtry te umożliwiają znaczne polepszenie jakości obrazu wynikowego, lecz nie na tyle, 
aby był on identyczny jak obraz zarejestrowany w warunkach statycznych. Może być to wadą w przypadku precyzyjnej oceny mikronierówności powierzchni przeprowadzanej podczas ruchu badanego przedmiotu w warunkach laboratoryjnych. Natomiast w przypadku kontroli aktywnej realizowanej w warunkach przemysłowych uzyskanie reprezentatywnego obrazu dla całej jednorodnej powierzchni może być dużą zaletą. $\mathrm{Na}$ podstawie takiego obrazu o uśrednionej wartości można, określić opracowane parametry struktury geometrycznej powierzchni przed lub po zakończeniu obróbki, które korelują z niektórymi parametrami standardowymi powierzchni.

\section{BIBLIOGRAFIA}

1. Umbaugh S.E. [ed.]: Computer Imaging: Digital Image Analysis and Processing. CRC Press, New York, 2005.

2. Kapłonek W.: Ocena topografii arkuszy ściernych $\mathrm{z}$ wykorzystaniem światła strukturalnego i komputerowej analizy obrazu. Pomiary, Automatyka, Kontrola, 5 (2006) 38-41.

3. Kapłonek W., Łukianowicz Cz.: Laser Scatterometry Used for Assessment of Microfinished Shafts. Proc. IV. International Congress on Precision Machining ICPM 2007, Vol.1, Section: Design \& Testing II, pp. 291-296.

4. Łukianowicz Cz., Iaquinta J.: Surface topography assessment of abrasive sheets by light scattering and self-shadowing methods. Archives of Civil and Mechanical Engineering, Vol. V, No. 2 (2005) 71-84.

5. Wiley, K. B., Chambers S.: Long Exposure Webcams and Image Stacking Techniques. The Art and Science of CCD Astronomy, 2nd edition. Ratledge D. [ed.], 2005. Wiley K.: How Image Stacking Works, http://www.cs.unm.edu/ kwiley/astroPhotography/imageStacking.html

6. White R.L., Helfand D.J., Becker R.H., Glikmane., de Vries W.: Signals from the Noise: Image Stacking for Quasars in the FIRST Survey. The Astrophysical Journal, 654 (2007), 99-114.

7. Schmitt H., Grass M., Heiland S., Hähnel S., Sartor K.: Image Stacking with Entropy Values in Conventional Angiography: Initial Experience. Radiology 230 (2004) 294-298.

8. Rabinowitz P., Sun C.: High Resolution Image Stacking in Geophysical Seismic Data Processing. Geophysical Research Abstracts, 9 (2007).

9. Kapłonek W., Łukianowicz Cz.: Zastosowanie skaterometrii laserowej i komputerowej analizy obrazu do oceny mikronierówności powierzchni będących w ruchu. XII Konf. "Metrologia w technikach wytwarzania", Augustów, 2007. Przegląd Mechaniczny 9 (2007) 119-124.

10. RegiStax - free software for alignment, stacking, processing of images, Cor Berrevoets http://registax.astronomy.net/

11. Image-Pro ${ }^{\circledR}$ Plus. Start-up Guide for Windows. Media Cybernetics, Inc., Silver Spring, MD, USA, 2004. http://www.mediacy.com 